\title{
Ningxia update: Government policy and measures for promoting a sustainable wine industry
}

\author{
Linhai $\mathrm{Hao}^{1}$, Xueming $\mathrm{Li}^{2}$, Kailong $\mathrm{Cao}^{2}$, and Huiqin $\mathrm{Ma}^{3}$ \\ ${ }^{1}$ Ningxia International Federation of Vine and Wine of Helan Mountain's East Foothill, Ningxia Hui Autonomous \\ Region 750000, China \\ ${ }^{2}$ Bureau of Grape Industry Development, Ningxia Hui Autonomous Region 750000, China \\ ${ }^{3}$ China Agriculture University, Beijing 100193, China
}

\begin{abstract}
The rapidly growing wine industry in the Ningxia region of north-central China had 35,300 ha of wine grapes and 184 registered wineries as of mid-2016. Ningxia's mission is to develop a sustainable wine industry based on small-scale producers and high-quality products in order to distinguish itself from other key regions in China. Government measures over the last two years have included diversifying grape varieties, encouraging vineyard mechanization, awarding cash to medalists in renown wine competitions, subsidizing international wine cooperation and education programs, and promoting local producers through Ningxia wine centers in major Chinese cities. These efforts have significantly improved wine quality, lowered costs and raised Ningxia's image as a region. The good reputation of Ningxia wine is now spreading from the trade to general consumers.
\end{abstract}

Résumé. L'industrie du vin en plein essor dans la région de Ningxia au nord-centre de la Chine compte 35300 ha de raisins de cuve et 184 établissements vinicoles enregistrés mi-2016. La mission de Ningxia est de développer une industrie de vin durable en base de petits producteurs et des produits de haute qualité afin de se distinguer des autres régions clés en Chine. Les mesures gouvernementales au cours des deux dernières années ont inclu la diversification des cépages, l'encouragement de la mécanisation des vignobles, l'attribution de l'argent aux médaillés des concours de vin renommés, les subventions aux programmes de coopération internationale sur le vin, la communication et éducation, la promotion des producteurs locaux par l'intermédiaire des Centres de vin Ningxia dans les grandes villes chinoises. Ces efforts ont considérablement amélioré la qualité du vin, abaissé les coûts et réhaussé l'image de Ningxia en tant qu'une région. La bonne réputation du vin Ningxia se répand désormais du commerce au grand public de consommateurs.

\section{Introduction}

China is both an important wine producer and wine market. According to OIV statistics for 2015, China ranked ninth worldwide in production, with 11 million $\mathrm{hl}$, and fifth as a market [1]. Wine imports in China have sharply risen over the past decade, averaging double digit annual growth. In 2015, import volume reached 5.5 million hl, including bottled and bulk wine, while value totaled just over USD2 billion (China Alcoholic Drinks Association, 2016).

Wine acceptance has grown significantly in China in recent years. Led by the example of central government leaders, consumers increasingly use wine for dinners, celebrations and daily use. Wine distributors, writers and consumers in China are becoming more knowledgeable and confident about wine. The Wine and Spirit Education Trust reported that over 9,000 mainland Chinese took its courses during the 2015-2016 school year-up 38\% from the previous period-making China its second biggest market [2]. Meanwhile, the rapid growth of Chineselanguage wine magazines, apps, websites and forums has made information easy to find for consumers. Imported wine has proliferated far beyond traditional sources such as five-star hotels and Western restaurants and is increasingly bought as more than an expensive present to be displayed or re-gifted. The price of imported wine has dropped remarkably in recent years and younger consumers, particularly in big cities and rich coastal areas, are drinking more for pleasure. There is also more imported wine available in the so-called third- and fourth-tier cities, due in part to the rise of large online retailers that deliver a wide range of choices at reasonable prices throughout the country.

The Chinese wine industry faces challenges from evolving consumer tastes and competitively priced imports. It also faces challenges in terms of growing conditions. China has a continental climate with a short autumn that affects ripening potential and harvest options. This situation, and traditional sales strategies focused on heavy marketing and personal connections rather than product quality, resulted in wines that were typically poor by international standards. In addition, the cold dry winters of northern China necessitate burying vines in the autumn and uncovering them in the spring, tasks that represent about $30 \%$ of production costs and can damage the plants. These quality and cost issues, paired with low 
brand recognition on Chinese wine in general and the competitivness of imports, have given Chinese wines an unfavorable market position.

The Ningxia wine industry is determined to establish a niche in this market. After evaluating the general Chinese wine sector, the Ningxia government created a strategy of encouraging small-scale wineries and focusing on wine quality, in contrast to other regions in China that have a greater commitment to scale. The mission is to become a world-renowned wine region.

\section{Material and methods}

This paper is based on documents from the Ningxia regional government, Bureau of Grape Industry Development and other relevant departments from 2012 to 2016 . It also draws on government statistics and interviews with industry leaders. The government documents used are listed in the reference section below.

\section{Results and discussion}

\subsection{Ningxia wine industry 2016}

The Ningxia wine industry has quickly developed over the past decade and reached 35,300 ha of wine grapes by the end of 2015. The number of wineries sharply increased from 130 at the end of 2014 to 184 by mid-2016.

After years of quick expansion, vineyard growth is now slowing. From 2010 to 2015, 4,000 ha of new wine grapes were planted per year on average, whereas 1,300 ha is expected for 2016. Ningxia has 3,000 ha of vines aged 11 years or older and 17,000 ha aged five to ten years. Improving existing vineyards ranks among the top tasks on the Ningxia government's agenda for 2016-2020. The aim is for $60 \%$ of vineyard coverage to reach international standards for quality wine grapes $[3,4]$.

Two policies were also announced for new plantings. First, only virus-free and traceable vine material is to be used. Before a batch of vines is planted, sampling will be done under the supervision of the Bureau of Grape Industry Development. In cases where viruses are detected, the material is to be destroyed [5]. Second, farmers will receive support for new wine grape vineyards only when they have a contract with a winery. Wineries are encouraged to plant and grow vineyards by contracting with farmers and by following the Bureau of Grape Industry Development standard created with the support of grape and wine experts [6]. This policy is meant to reduce the risk of chaotic vineyard development and, in turn, large wine grape surpluses.

\subsection{Encouraging grape variety diversification}

At present, $75 \%$ of the wine grapes in Ningxia are Cabernet Sauvignon and typically used to emulate Bordeaux-style wines. Although these wines are responsible for most of the medals won by Ningxia in contests, diversification of grape varieties and wine styles could help the region better cope with the evolving market. If more than 13 ha of a wine grape variety beyond Cabernet Sauvignon, Cabernet Gernischt, Merlot and Chardonnay has been planted, and a new marketable wine is made from that variety, the government will award USD 15,000 to the winery [6]. At present, the 40-plus varieties under evaluation include
Riesling, Petit Verdot, Marselan and Shiraz as well as Beihong and Beimei, two Chinese-bred varieties with a V. amurensis background.

\subsection{Cost control by mechanization and viticulture}

China's harsh northern winters require burying vines each fall, often in a very short time, and uncovering them each spring. Given this represents $30 \%$ or more of wine grape production costs, and that there are growing concerns about labor scarcity, mechanization is the future for Ningxia's vineyards. To encourage mechanization, and thus improve efficiency, control costs and potentially lower wine prices, standardized vineyard designs are being promoted. The vineyard features include widened lanes to facilitate tractors, supporting poles made of wood and metal, rather than cement, and aligned using GPS, and a shift from vertical training systems to modified cordon or Guyot ones. Standardizing vineyards is a precondition for mechanization.

Most grape farmers and wine producers are smallscale and do not possess all of the necessary equipment, thus creating a need for vineyard machine services. To meet this need, machine service stations are being encouraged, with up to $30 \%$ of the purchasing cost or a maximum of USD 40,000 being reimbursed by the government [6]. At present, equipment services are mainly used for burying vines, pulling vines and spraying for disease control. Smart viticulture strategies using cuttingedge technology can also help control costs and boost environmental friendliness. The most recent effort is an app developed to provide meteorological information for vine burying, vine pulling, frost warning and plant disease risk forecasts.

\subsection{Encouraging international cooperation}

Ningxia sees imported wines not as foes but as healthy competitors in a market dominated by spirits and beer. In 2015, Chinese consumed 471.6 million hl of beer, 131.3 million $\mathrm{hl}$ of hard liquor (calculated at an alcohol content of $65 \%$ ), and 27.3 million hl of Chinese rice wine (China Alcoholic Drinks Association, 2016). The joint efforts of the domestic and imported wine trades will help increase wine consumption and its share of the alcoholic drink market. Improving wine quality and encouraging consumption based on taste rather than simply for "face" or status reasons is important for creating a sustainable industry.

China's modern wine industry is relatively new and its production chain requires fine-tuning, including in areas such as quality grape growing, winemaking technology, wine business management, and brand promotion and marketing. To quickly fill the knowledge gap, the Ningxia government is strengthening its outreach efforts. Learning from wine regions with international reputations is crucial to quick quality improvement, stronger results in competitions, and perfecting unique wine styles, including those that reflect Ningxia's terroir. Following the success of the first Ningxia Wine Challenge from 2012 to 2014, 48 international winemakers were recruited last year for a second challenge that partners each with a local winery. Diverse wine styles and personal stamps 
are expected from these partnerships. As in the first challenge, Chinese assistant winemakers work with the visiting winemakers. Moreover, Ningxia wine delegations are visiting "Old World" and "New World" wine regions to gather information and exchange ideas. And new education programs focused on the wine business are being planned in cooperation with several of the world's leading universities.

\subsection{Regional promotion and wine tourism}

Quality wines are the foundation of Ningxia's wine industry and require consistent promotion to generate the cash flow needed for sustainability. Given this, wine region promotion is an important government focus. The airport in the regional capital of Yinchuan has a shop, supported by the Ningxia Bureau of Grape Development, with local wines that have won medals in major international contests or the annual Ningxia Wine Competition.

Medals gained in renown contests are helpful for facilitating trust with consumers. To encourage wine quality and brand building, the Ningxia government is awarding USD 50,000 to wines that win gold medals in the Concours General Agricole Paris, Concours Mondial de Bruxelles or Decanter World Wine Awards, and that have been covered at least once by the Chinese media [6].

Ningxia wine centers were established in Beijing, Shanghai and Guangzhou in 2016. Upon completing one year of smooth operations, and fulfilling a list of promotion tasks, each center will receive USD 150,000 over two years from the Ningxia government.

Wine tourism is yet another important way to raise regional recognition as well as fortify the winery-consumer relationship and promote direct sales for small producers. Ningxia has heavily invested in roads, public service facilities and environmental protection in areas with the highest concentrations of wineries [7,8]. A 25-km long wine route has been built that includes a tourist center and road signs [9]. Wineries are also encouraged to develop their own tourist services. Official winery ratings are based on the establishment of a minimum level of facilties [10]. Ningixia has a U.S.-China tourism year this year and wine will play a signficiant role, with 350,000 wine tourism visits expected in 2016.

\section{Conclusions}

The Ningxia government has made significant efforts to build a sustainable wine industry, pursuing a general policy of "small wineries and big wine region." Wineries are encouraged to have their own vineyards or to make long-term contracts with farmers. Efforts are being made to produce high quality wines from standardized vineyards with optimized cost control practices. And the region's wines are being supported through Ningxia wine centers, exhibitions in major Chinese cities and tourism development. Ningxia is continuing on its path of making policies and undertaking measures to realize the sustainable development of its wine region and to ultimately harvest the fruits of its "small is big" mission.

The authors appreciate the support of China Alcoholic Drinks Association. This document was edited by Jim Boyce.

\section{References}

[1] International Organisation of Vine and Wine. 2016. http://www.oiv.int/en/

[2] Wine and Spirits Education Trust. 2016. https://www. wsetglobal.com/

[3] Bureau of Grape Industry Development, Ningxia Hui Autonomous Region People's Government. 2015. Notification on launching quality vineyards contest of Ningxia Wine Region. (In Chinese)

[4] Management Committee of Ningxia Helan Mountain East Foothill Grape Industry Park. 2015. Guide on strengthening the management of the wine grape base. (In Chinese)

[5] Department of Forestry, Ningxia Hui Autonomous Region People's Government. 2016. Notification on releasing the regulation on grapevine materials of the Helan Mountain East Foothill Wine Region. (In Chinese)

[6] Management Committee of Ningxia Helan Mountain East Foothill Grape Industry Park. 2016. Notification on the release of methods of new financial support to enhance the development of the grape industry and measures for implementation. (In Chinese)

[7] Department of Environmental Protection, Ningxia Hui Autonomous Region People's Government. 2012. Suggestions of the General Office of Ningxia Autonomous Region People's Government on strengthening the environmental protection work for wine origin of geographical indications of Helan Mountain East Foothill. (In Chinese)

[8] Ningxia Hui Autonomous Region People's Government. 2012. Regulations of Ningxia Hui Autonomous Region on the protection of Helan Mountain East Foothill wine region. (In Chinese)

[9] Ningxia Hui Autonomous Region People's Government. 2012. Suggestions of Ningxia Autonomous Region People's Government on the promotion of development of the grape industry and cultural corridor of Helan Mountain East Foothill. (In Chinese) General Office, Ningxia Hui Autonomous Region People's Government. 2014. Guidelines on strengthening the quality supervision, brand protection and market regulation of wines of the Helan Mountain East Foothill. (In Chinese)

[10] General Office, Ningxia Hui Autonomous Region People's Government. 2016. Notification on regulations of winery classification assessment. (In Chinese) 